\section{PHYSICAL INACTIVITY, CHRONIC DISEASES, IMMUNITY AND COVID-19}

INATIVIDADE FÍSICA, DOENÇAS CRÔNICAS, IMUNIDADE E COVID-19

INACTIVIDAD FISICA, ENFERMEDADES CRÓNICAS, INMUNIDAD YCOVID-19

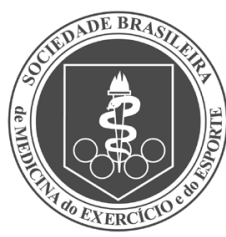

SPECIAL ARTICLE

ARTIGO ESPECIAL

Articulo espeCial

\begin{abstract}
Thiago Teixeira Guimarães ${ }^{1}$ (Physical Education Professional) Henrique Mariano Brito dos (iD) Santos ${ }^{1}$

(Physical Education Professional)

Rodrigo Terra Mattos Sanctos ${ }^{1,2}$ (iD (Physical Education Professional)

1. Excessive Exercise Research Group (GPEEx), Rio de Janeiro, RJ, Brazil.

2. Colégio Brigadeiro Newton Braga (CBNB), Directorate of Education, Brazilian Air Force (DIRENS/FAB), Rio de Janeiro, RJ, Brazil.
\end{abstract}

\section{Correspondence:}

Thiago Teixeira Guimarães

Av. Lucio Costa, 3550, Barra da

Tijuca, Rio de Janeiro, RJ, Brazil. 22630-010.

thiagotguimaraes@yahoo.com.br

\begin{abstract}
Complications arising from COVID-19 reflect an abnormal immune response in people previously diagnosed with chronic, non-communicable diseases (NCD), such as cardiovascular, metabolic and pulmonary conditions. Physical inactivity is recognized as a condition that affects the development of chronic low-grade inflammation, NCD, and susceptibility to cell infections. Anxiety and mental stress, poor nutritional status, drug use and circadian rhythm disturbances can further aggravate the harm caused by physical inactivity. Therefore, the purpose of the review is to invite health professionals, their respective regulatory boards, universities, research promotion foundations, media, political authorities and lay citizens to raise awareness of immunity and health in the medium- to long-term control of the current pandemic. Level of evidence V; Expert opinion.
\end{abstract}

Keywords: Pandemic; Physical exercise; Inflammation; SARS-CoV-2.

\section{RESUMO}

As complicações decorrentes da COVID-19 refletem uma resposta imune irregular em pessoas previamente acometidas por doenças crônicas não transmissivivis (DCNT), como por exemplo, cardiovasculares, metabólicas e pulmonares. A inatividade física é reconhecidamente uma condição que impacta o desenvolvimento de inflamação crônica de baixo grau, DCNT e suscetibilidade a infecções celulares. Ansiedade e estresse mental, estado nutricional deficiente, consumo de drogas e ritmo circadiano perturbado podem agravar ainda mais os prejuízos da inatividade física. Sendo assim, o objetivo da revisão é convidar profissionais da área da saúde, seus respectivos conselhos regulatórios, universidades, fundações de amparo à pesquisa, mídia, autoridades políticas e cidadãos leigos para a conscientização sobre imunidade e saúde no controle em médio a longo prazo da atual pandemia. Nível de evidência V; Opinião do especialista.

Descritores: Pandemia; Exercício físico; Inflamação; SARS-CoV-2.

\section{RESUMEN}

Las complicaciones derivadas del COVID-19 reflejan una respuesta inmune irregular en personas previamente afectadas por enfermedades crónicas no transmisibles (ECNT) como, por ejemplo, cardiovasculares, metabólicas y pulmonares. La inactividad física es reconocidamente una condición que impacta en el desarrollo de inflamación crónica de bajo grado, ECNT y susceptibilidad a infecciones celulares. La ansiedad y el estrés mental, el estado nutricional deficiente, el consumo de drogas y el ritmo circadiano alterado pueden agravar aún más los perjuicios de la inactividad física. Por lo tanto, el objetivo de la revisión es invitar a profesionales del área de la salud, a sus respectivos consejos reguladores, universidades, fundaciones de apoyo a la investigación, medios de comunicación, autoridades políticas y ciudadanos laicos para la concienciación sobre inmunidad y salud en el control a mediano y largo plazo de la actual pandemia. Nivel de evidencia V; Opinión del especialista.

Descriptores: Pandemias; Ejercicio físico; Inflamación; SRAG-CoV-2.

\section{INTRODUCTION}

An increasing number of people are affected by NCDs such as obesity, cardiovascular, metabolic, pulmonary and renal diseases as well as various types of cancer and mental, bone, and joint disorders..$^{1-4}$ In addition to suffering, functional dependence and intangible investments in health systems, in 2016, an estimated 41 million adult deaths were attributed to these diseases, representing $71 \%$ of the total for this population in the world. ${ }^{4}$ In Brazil, NCDs correspond to around $70 \%$ of the causes of death in adults and a similar percentage in Brazilian Unified Health System (Sistema Único de Saúde - SUS) expenditures. ${ }^{5}$
Physical inactivity features as one of the main causes attributed to the development of $\mathrm{NCD}^{1,6}$ and the worsening of clinical conditions due to COVID-19 is related to a previous diagnosis of inflammation and NCD.? In Brazil, according to a survey published on the official website of the Ministry of Health, in mid-April (2020), seven out of every 10 COVID-19 deaths recorded were of people over 60 years of age with at least one risk factor, such as heart or lung disease and diabetes. The Brazilian Ministry of Health also stated that people of any age with NCD are also in the high risk group, and need to redouble their efforts to take preventive steps to avoid COVID-19. ${ }^{8}$ 
There is classic epidemiological ${ }^{1,6}$ and biological9-12 evidence supporting moderate physical activity. Its potential benefits include the regulation and promotion of organ systems such as the nervous, cardiovascular, endocrine, respiratory, renal, digestive, and immune systems. ${ }^{9-12}$ Although physical activity has been encouraged during the pandemic, a better understanding of its role in modulating the immune system, as a stress stimulus, can allow a more solid, contextualized and permanent dissemination of its practice combined with other environmental factors (multifactorial approach). After all, viruses, such as Sars-CoV-2, undergo genetic mutation constantly and hinder remedial actions. Hence prevention against physiological and social chaos is indisputably the best solution.

\section{Basic considerations about immune response and stress}

The role of the immune system is to recognize normal and abnormal processes in the human body to repair possible damage and preserve homeostasis, in cooperation with other physiological systems. ${ }^{12-14}$ When carrying out its functions, the immune system can be divided into two categories: natural or innate immunity and acquired or adaptive immunity. 12-14

The natural or innate immune response is immediate and includes physical (e.g., skin) and chemical (e.g. tear, complement system) barriers, as well as the participation of phagocytic cells such as neutrophils, macrophages, dendritic cells and natural killers (NK), in addition to microbicidal molecules such as nitric oxide (NO) and superoxide anion. . $2-14^{-14}$ It has limited specificity and does not develop memory.

The acquired or adaptive immune response has high specificity, in addition to developing memory, and can be divided into cellular and humoral/extracellular. The cellular immune response is mainly mediated by type 1 (Th1) auxiliary CD4+ T lymphocytes, type 1 cytotoxic CD8+ T lymphocytes, and cytokines (e.g. IFN-Y, TNF, IL-1, IL-2, IL-12, IL-17). ${ }^{12-15}$ It is also worth emphasizing the participation of macrophages and dendritic cells both in phagocyte function and in relation to the production of cytokines and presentation of antigens to virgin T lymphocytes for their differentiation. ${ }^{12-14}$ Mutual stimulation of macrophage and lymphocyte functions represents an important mechanism for amplifying specific immunity. ${ }^{12}$

In the humoral/extracellular immune response, it is possible to highlight B lymphocytes, antibodies, type 2 (Th2) auxiliary CD4+ T lymphocytes, type 2 cytotoxic CD8+T lymphocytes, and cytokines (e.g., $\mathrm{IL}-4, \mathrm{IL}-5, \mathrm{IL}-10$ and IL-13). ${ }^{12-15} \mathrm{An}$ important population in the harmony between cellular and humoral immunity is that of regulatory $T$ cells, activated by cytokines such as IL-2, IL-10 and TGF- $\beta .^{14}$ These cells are responsible for inhibiting the proliferation of effector T lymphocytes. ${ }^{14}$ Their deficiency is related to inflammation and the development of severe autoimmune syndromes. ${ }^{14}$

Although there is no known consistent evidence of the blocking of Sars-CoV-2 reproduction to date, it is important to consider balance and integration between innate, cellular and humoral immunity against viruses. There is the production of type 1 interferons (IFN-alpha and beta), which act by inhibiting viral replication, thereby creating the so-called antiviral state, as well as the action of NKs, destroying cells infected by viruses. Moreover, the production of neutralizing antibodies produced by B lymphocytes, while still in the extracellular phase of the virus, blocks their entry into the target cell and the recognition of the viral antigen, with subsequent destruction of the infected cell by cytotoxic CD8+ T lymphocytes, representing important pathways against viruses due to adaptive immunity. ${ }^{13,4}$ In Sars-CoV-2 infection, when the body is unable to develop an adequate acquired response, persistent inflammation induced by innate immunity favors disease severity. ${ }^{16}$

The immunity of an asymptomatic and previously "healthy" organism is usually able to resolve intracellular infections. ${ }^{17,18}$ Under these conditions, a possible explanation for efficient repair is the balance between cellular and humoral responses, with a slight predominance of the cellular profile, ${ }^{17-22}$ as its exacerbation can result in tissue damage. ${ }^{15}$ However, in situations of cumulative and/or NCD, i.e., when homeostasis is compromised prior to infection, chronic inflammation and/or immunity imbalance would appear to favor cell vulnerability. ${ }^{15}$ In actual fact, the immune response is extremely complex and involves numerous mechanisms, but to corroborate this hypothesis, two examples are presented.

The senescence of the organism is accompanied by changes in the immune system (immunosenescence). ${ }^{23}$ Chronic low-grade inflammation associated with the aging process (inflammaging) can be explained by the decline in immune function, changes in innate immunity and imbalance between cellular and humoral immunity, contributing to a greater risk of exposure to pathogens in this population. ${ }^{24,25}$ In addition, the "open window of opportunity", traditionally discussed in exercise and sport sciences for three decades, has been associated with the imbalance between cellular and humoral immunity. ${ }^{15,26}$ Following this theoretical rationale, the level of physiological stress and disturbance of homeostasis appears to be determinant for cellular susceptibility.

Stress is essential in adaptive processes, whether physical, chemical or psychological. It can be regarded as a wide-ranging set of events, consisting of a stressor stimulus, a reaction processed in the central nervous system, and responses such as fight-flight (or freeze). ${ }^{27}$ To preserve homeostasis in stressful situations, several chemical messengers, such as cytokines, are secreted and act in an autocrine, paracrine and endocrine manner. These proteins not only orchestrate specific immunity, but also integrate the immune, nervous, endocrine, cardiovascular, renal, digestive and hematopoietic systems. ${ }^{12-14}$

Interestingly, in previously inflamed organisms (e.g., with NCD) that are more vulnerable to Sars-CoV-2, the development of the "cytokine storm syndrome" is suggested. ${ }^{28}$ While in balanced conditions the cytokines act efficiently in low concentrations, cytokine "storms" frequently observed in the more severe cases of COVID-19 reflect hyperinflammation, ${ }^{28}$ supposedly triggered by an exacerbated response to the alarm reaction caused by stress (infection). Tissue and functional damage in systems (e.g., the respiratory system) is imminent.

\section{Basic considerations about immune response and physical exercise}

Controlled doses of physical, chemical or environmental stimuli, with the potential to cause harm in higher amounts, appear to induce positive chronic effects on cells, tissues, organs and physiological systems. ${ }^{29}$ Physical exercise is included in this context. One of the various arguments to encourage moderate and periodic exercise refers to the protection of cells against infections caused by intracellular microorganisms (e.g., viruses), based on the balance between cellular and humoral immune responses, with discreet readiness for the Th1 profile. ${ }^{17-19}$

For example, data from our group revealed that lymph node cells and mouse macrophage supernatants, after 10 to 12 weeks of moderate exercise, expressed more pro-inflammatory cytokines (e.g., IFN- $y$ and TNF), while the concentration of anti-inflammatory cytokines (e.g., lL-4 and IL-10) decreased significantly compared to the physically inactive group. ${ }^{17,18,30}$ The reduction of the post-intervention IL-10/IFN- $\gamma$ ratio converged with the hypothesis of the predisposition of the protective cell profile (Th1) with moderate exercise. ${ }^{15,17-19,30}$ Furthermore, macrophages of mice infected with the protozoa Leishmania major produced more IL-12 and NO compared to macrophages in the sedentary control group. ${ }^{17,18}$ We should also take note of the greater microbicidal activity of these cells and the reduction infection rates and the number of parasites isolated from the paw of infected animals..17,18 The moderate physical training protocol has proven capable of controlling disease development, ${ }^{17,18}$ corroborating classical theories of exercise and immunity in health, aging, and quality of life. ${ }^{15,31-33}$ 
In fact, randomized controlled clinical trials may allow greater robustness in terms of the hierarchy of scientific evidence. However, it should be emphasized that experiments on humans must protect their physical and emotional well-being, and that the use of animal models for in vivo and in vitro infections is crucial. Institutional review boards would censure more robust studies on the effect of exercise on modulating the immune response in people against different pathogens (e.g., viruses, bacteria, protozoa and helminths).

It should be noted, however, that any physical exercise program alone does not guarantee permanent positive effects. ${ }^{26} \mathrm{~A}$ study presented by our group in 2019, on chronic stress-induced excessive stress, verified the impairment of the cellular immunity of mice macrophages in these conditions. ${ }^{30}$ Aerobic training of considerably high volume not only impaired the physical performance of our study sample, but also increased the participants'susceptibility to protozoan infections in macrophages, parallel to the predominance of Th2 profile, conditions similarly observed in the physically inactive group..$^{30}$ Moderate training, on the other hand, served to protect against cell infections and showed a predominance of Th1 profile. $^{30}$

There appears to be a consensus that immune responses to exercise reflect individual cumulative physiological and metabolic stress. ${ }^{26}$ The multifactorial approach is crucial as it takes into account factors such as sleep, anxiety, mental fatigue, nutrition, history of infections, personal hygiene, frequency of travel and weather conditions (environmental extremes). ${ }^{26}$ It is known that a balanced diet can, among several other benefits, prevent the deviation of the metabolic route of amino acids, which are vital for the health of macrophages, during situations of prolonged stress or inadequate protein intake. ${ }^{34,35}$ In addition, severe carbohydrate restrictions may favor chronic cortisol elevation and contribute to the cell immunosuppression process. ${ }^{36}$ Regular sleep is essential for the balance of the immune system and the relationship between anabolic and catabolic hormones. ${ }^{37}$ Anxiety, fear and general concerns can trigger a "permanent" fight-or-flight response and chronic mental stress, ${ }^{38}$ completely unbalancing the immune system and making it more vulnerable.

\section{Suggestions for medium- to long-term public health actions}

- Joint actions to encourage practices that promote immunity and health can lessen the effects of the economic, political and social crisis in Brazil, as new outbreaks have been reported worldwide. It is suggested that physical activity be encouraged along with raising awareness of strategies to control mental stress and anxiety, diet, circadian rhythm, use of legal (e.g., medicinal products, tobacco, alcohol, other psychoactive substances such as caffeine), and illegal drugs.

- For a physical activity to have potentialized benefits and reduced risks, it is important to consider a minimum structuring and contextualization with other stress factors/stimuli. Professional guidance is relevant in this regards, as it transforms physical activity into physical exercise. Basic principles and concepts of the prescribing practice must be respected so that sedentary individuals, elite, amateur and recreational athletes develop or maintain physical fitness and health, avoiding the trigger for cell immunosuppression or any other type of side effect of movement (e.g., injuries, apathy, chronic fatigue, paradoxical deconditioning or exacerbated biological responses to the alarm reaction arising from all kinds of stress).

- It is known that health is not merely the absence of disease. The use of chemical products is an extremely important practice during the pandemic, but becomes limited in the medium to long term if cellular and humoral immunity are not in harmony (e.g., sedentary lifestyle). In addition, these products, when prescribed in excess, can compromise the microbiota and the symbiotic relationship favorable to coevolution. ${ }^{39}$ It would be advisable to draw attention to the importance of their conscious and moderate use, combined with the development of immunity and health. - Worldwide pandemics are overlapping. The inability of the immune system to respond to stress to preserve homeostasis appears to be associated with chronic inflammation, physical inactivity and/or unsatisfactory cardiorespiratory fitness. Taking into account the high risk of contagion in closed environments for collective use and the matter of exercise adherence, it may be a good time to rethink actions to combat a sedentary lifestyle. For instance, people who go for walks in the countryside significantly reduce the activation of areas of the brain responsible for ruminative thinking (e.g., induced by resentments and cumulative responsibility), which are associated with mental exhaustion and depression. ${ }^{40}$ Can physical activities in natural environments adjust the production of neurotransmitters such as dopamine, serotonin, anandamide, endorphin and oxytocin, thereby activating the brain's limbic reward system, promoting positive intrinsic reinforcement, balancing different physiological systems, and providing more quality to psychological, immunologic and stress response functions?

- The predisposition of the human body to numerous diseases, due to physical inactivity or interference with homeostasis, is incompatible with public health values and hypotheses. Professionals from the area, their respective regulatory boards, universities, research promotion foundations, media, political authorities and lay citizens are invited to take actions that go far beyond fighting disease. There is an urgent need to practice immunity and health. The "green light" in Figure 1 should be encouraged in order to reduce the impact of the "amber light" on the development of the "red light".

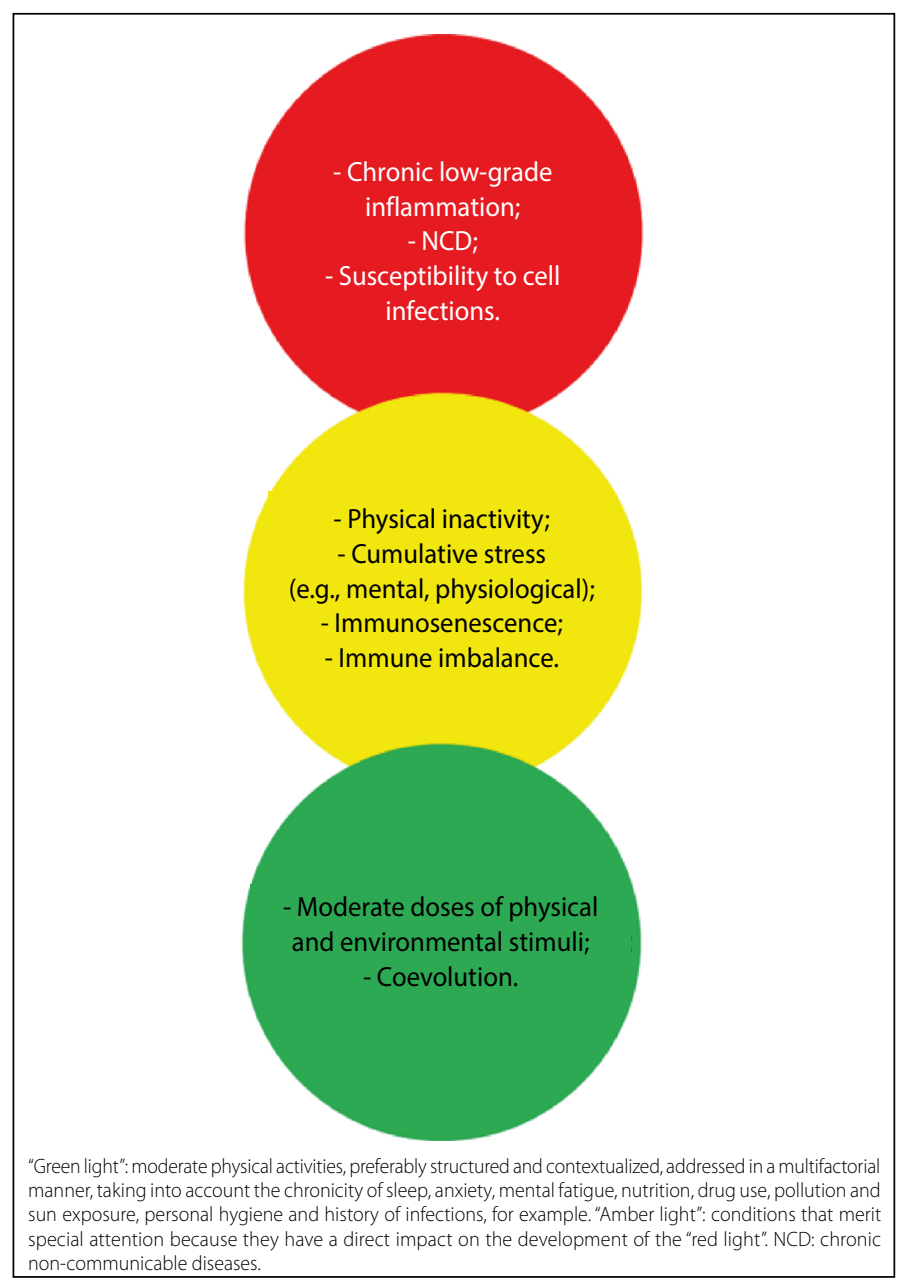

Figure 1. Relationship between physical inactivity, NCD, stress, immunity, infections and associated factors. 


\section{CONCLUSION}

Health professionals, their respective regulatory boards, universities, research promotion foundations, media, political authorities and lay citizens are expected to raise awareness of the relationship between physical inactivity, poor nutritional status, mental stress, immunity and health for the medium to long-term control of the current pandemic and the prevention of similar situations in the future.

All authors declare no potential conflict of interest related to this article.

AUTHORS' CONTRIBUTIONS: Each author made significant individual contributions to this manuscript. TTG, HMBS and RTMS: substantial contribution to the conception or design of the work, data acquisition, analysis or interpretation, writing of the work. TTG, RTMS: critical review of the intellectual content and approval of the final version of the article. All authors read, agreed to, and accepted responsibility for, all aspects of the work, with a view to ensuring that any issues related to the integrity or accuracy of any of its parts are properly investigated and resolved.

\section{REFERENCES}

1. Handschin C, Spiegelman BM. The role of exercise and PGC1 alpha in inflammation and chronic disease. Nature. 2008;454(7203):463-9.

2. Lee IM, Shiroma EJ, Lobelo F, Puska P, Blair SN, Katzmarzyk PT, et al. Effect of physical inactivity on major non-communicable diseases worldwide: an analysis of burden of disease and life expectancy. Lancet. 2012; 380(9838):219-29.

3. World Health Organization (WHO). Noncommunicable diseases country profiles. 2014. Pakistan, Geneva, Switzerland: World Health Organization; 2014.

4. World Health Organization (WHO). World health statistics 2018: monitoring health for the SDGs, sustainable development goals. Geneva: World Health Organization; 2018.

5. Ministério da Saúde. Plano de ações estratégicas para o enfrentamento das doenças crônicas não transmissíveis (DCNT) no Brasil, 2011-2022. Brasília: Ministério da Saúde; 2011.

6. Hallal PC, Andersen LB, Bull FC, Guthold R, Haskell W, Ekelund U, et al. Global physical activity levels: surveillance progress, pitfalls, and prospects. Lancet. 2012;380(9838):247-57.

7. Stefan N, Birkenfeld AL, Schulze MB, Ludwing DS. Obesity and impaired metabolic health in patients with COVID-19. Nat Rev Endocrinol. 2020;16(7):341-2.

8. MINISTÉRIO DA SAÚDE, B., [Internet]. 2020 [acesso em 2020 set 21]; https://www.saude.gov.br/ noticias/agencia-saude/46753- brasil-registra-38-654-casos-confirmados-de-coronavirus-e-2-462-mortes, 2020.

9. Booth FW, Chakravarthy MV, Spangenburg EE. Exercise and gene expression: physiological regulation of the human genome through physical activity. J Physiol. 2002;543(Pt 2):399-411.

10. Fiuza-Luces C, Garatachea N, Berger NA, Lucia A. Exercise is the real polypill. Physiology (Bethesda). 2013; 28(5):330-58..

11. Heinonen I, Kalliokoski K, Hannukainen JC, Duncker DJ, Nuutila P, Knuuti J. Organ-specific physiological responses to acute physical exercise and long-term training in humans. Physiology (Bethesda). 2014;29(6): 421-36.

12. Terra R, Silva SA, Pinto VS, Dutra PM. Effect of exercise on immune system: response, adaptation and cell signaling. Rev Bras Med Esporte. 2012;18(3):208-14.

13. Murphy KM. Imunbiologia de Janeway. 8 ed. Porto Alegre: Artmed; 2014.

14. Abbas AK, Lichtman AH, Pillai S. Imunologia celular e molecular. 9 ed. Rio de Janeiro: Elsevier; 2019.

15. Zhao G, Zhou S, Davie A, Su Q. Effects of moderate and high intensity exercise on $\mathrm{T} 1 / \mathrm{T} 2$ balance. Exerc Immunol Rev. 2012;18:98-114.

16. Ahmadpoor P, Rostaing L. Why the immune system fails to mount an adaptive immune response to a COVID-19 infection. Transpl Int. 2020;33(7):824-5

17. Terra R, Alves PJ, Silva SA, Salermo VP, Dutra PM. Exercise improves the Th1 response by modulating cytokine and NO production in BALB/C mice. Int J Sports Med. 2013;34(7):661-6.

18. Terra R, Alves PJ, Lima AK, Gomes SM, Rodrigues LS, Salerno VP, et al. Immunomodulation from moderate exercise promotes control of experimental cutaneous leishmaniasis. Front Cell Infect Microbiol. 2019;9:115.

19. Guimarães TT, Terra R, Dutra PM. Chronic effects of exhausting exercise and overtraining on the immune response: Th1 and Th2 profile. Motricidade. 2017;13(3):69-78.

20. RuW, Peijie C. Modulation of NKT cells and Th1/Th2 imbalance after alpha-GalCer treatment in progressive load-trained rats. Int J Biol Sci. 2009;5(4):338-43.
21. Farhangimaleki N, Zehsaz F, Tiidus PM. The effect of tapering period on plasma pro-inflammatory cytokine levels and performance in elite male cyclists. J Sports Sci Med. 2009;8(4):600-6.

22. Gholamnezhad Z, Boskabady MH, Hosseini M, Sankian M, Rad AK. Evaluation of immune response after moderate and overtraining exercise in wistar rat. Iran J Basic Med Sci. 2014;17(1):1-8.

23. Dorshkind K, Montecino-Rodriguez E, Signer RA. The ageing immune system: is it ever too old to become young again? Nat Rev Immunol. 2009;9(1): 57-62.

24. Shearer GM. Th1/Th2 changes in aging. Mech Ageing Dev. 1997;94(1-3):1-5.

25. Schmitt V, Rink L, Uciechowski P. The Th17/Treg balance is disturbed during aging. Exp Gerontol. 2013;48(12):1379-86.

26. Simpson RJ, Campbell JP, Gleeson M, Krüger K, Nieman DC, Pyne DB, et al. Can exercise affect immune function to increase susceptibility to infection? Exerc Immunol Rev. 2020;26:8-22.

27. Dickerson SS, Kemeny ME. Acute stressors and cortisol responses: a theoretical integration and synthesis of laboratory research. Psychol Bull. 2004; 130(3):355-91.

28. Mehta P, McAuley DF, Brown M, Sanchez E, Tattersall RS, Manson JJ, et al. COVID-19: consider cytokine storm syndromes and immunosuppression. Lancet. 2020;395(10229):1033-4.

29. Radak Z, Chung HY, Goto S. Systemic adaptation to oxidative challenge induced by regular exercise. Free Radic Biol Med. 2008;44(2):153-9.

30. Guimarães T, Terra R, Dutra P. Excesso de exercício físico aumenta a suscetibilidade de infecções em macrófagos. Rev Bras Med Esporte. Anais do 310 Congresso Brasileiro de Medicina do Exercício e do Esporte. 2019;25(5):3.

31. Shephard RJ. Development of the discipline of exercise immunology. Exerc Immunol Rev. 2010;16:194-222.

32. Pedersen BK, Hoffman-Goetz L. Exercise and the immune system: regulation, integration, and adaptation. Physiol Rev. 2000;80(3):1055-81.

33. Gleeson M, Bishop NC, Stensel DJ, Lindley MR, Mastana SS, Mimmo MA. The anti-inflammatory effects of exercise: mechanisms and implications for the prevention and treatment of disease. Nat Rev Immunol. 2011;11(9):607-15.

34. Rowbottom DG, Keast D, Morton AR. The emerging role of glutamine as an indicator of exercise stress and overtraining. Sports Med. 1996;21(2):80-97.

35. Bassit RA, Sawada LA, Bacurau RF, Navarro F, Costa Rosa LF. The effect of BCAA supplementation upon the immune response of triathletes. Med Sci Sports Exerc. 2000;32(7):1214-9.

36. Braun WA, Von Duvillard SP. Influence of carbohydrate delivery on the immune response during exercise and recovery from exercise. Nutrition. 2004;20(7-8):645-50.

37. Micić DD, Sumarac-Dumanovic M, Susic V, Pejkovic D, Polovina S. Sleep and metabolic disorders. Glas Srp Akad Nauka Med. 2011;(51):5-25.

38. Hasan KM, Rahman Md S, Arif KM, Sobhani ME. Psychological stress and aging: role of glucocorticoids (GCs). Age (Dordr). 2012;34(6):1421-33.

39. Ram H, Dastager SG. Re-purposing is needed for beneficial bugs, not for the drugs. Int Microbiol. 2019;22(1):1-6.

40. Bratman GN, Hamilton JP, Hahn KS, Daily GC, Gross JJ. Nature experience reduces rumination and subgenual prefrontal cortex activation. Proc Natl Acad Sci U S A. 2015;112(28):8567-72. 